\title{
A comparison of learning the digestion process with comic strips and endoscopic video: the effects on student's achievement and its contributing factors
}

\author{
Ikmanda Nugraha ${ }^{1}$, Lilit Rusyati ${ }^{2}$ and Rika Rafikah Agustin ${ }^{3}$ \\ \{ikmandanugraha@upi.edu ${ }^{1}$, lilitrusyati@upi.edu², rikarafikah@upi.edu $\left.{ }^{3}\right\}$ \\ International Program on Science Education, Faculty of Mathematics and Science Education, \\ Universitas Pendidikan Indonesia ${ }^{1,2,3}$
}

\begin{abstract}
Comic strips and videos are two popular media used in today's science education. The objectives of this study were to examine the learning outcomes and to explore the contributing factors that drive students to achieve the learning outcomes. A quasi-experimental design was employed. The participants were university students in the science education major from batch 2015 and 2016. Batch 2015 was assigned as an endoscopic video class while batch 2016 was assigned as comic strips class. The results showed that there was no significant difference in students learning outcomes and its highest contributing factor for the learning outcomes was personal motivation followed by the lecturer and the media. We conclude that both media were able to facilitate students learning outcomes but motivating students' personal motives was also essential due to the nature of university students as an independent learner.
\end{abstract}

Keywords: learning digestion process, comic strips, endoscopic video

\section{Introduction}

Comic strips and videos are two popular media used in today's science education. Comic strips have an interesting way to give information with a narrative story in the image form that facilitates learning because they act as mnemonic elements that could influence an individual's long-term memory [1]. The common form of comic strips may be included as a short comic strip, comic books or even graphic novels, these forms are varied according to their needs to deliver the information by the comics itself. Hence, science comic refers to the medium that uses a humorous illustrated narrative to transfer the information of science. The previous studies revealed that humor can stimulate the reader's positive emotional and intrinsic motivation to improve their interest in learning of science [2].

Students' motivation can be improved by comic since there is a combination of text and image. Furthermore, comic gives the chance to engage students for a positive attitude [3]. Scientific literacy also can be assisted by using a science comic. Comic is a well-like art for young generations so be able to be teaching media for science learning [4]. In addition to teaching media for the teacher, science comic potential for facilitating students to design dan compose their own nonfiction which relates to a science topic. Consequently, students will be critical consumers and producers of information in science comic [5]. For graduate students and young scientists, science comic strips notify proper philosophy for their job that in line with science [6]. 
The use of comics in science lessons has already been carried out by some studies [7] [8] [9]. Comic showed a positive effect on reading literacy, reading motivation and interest [10] [11]. In addition, the visual associations provided by educational comics support the understanding of abstract concepts better than a long text written in more-or-less strictly scientific language [12]. In terms of student achievement, humor in science comics engages middle-lever achievers more than high-level achievers [8], and comics in science education can engage and convey science knowledge among a broad diversity of students [13].

In the era of technology, many features to facilitate scientists for developing a video that can apply in the learning process [14]. Learning performance and students' satisfaction in the class that uses interactive video is higher than the class that non-interactive video provided [15]. Another aspect which has been improved by using video is adolescents' self-regulated learning outcomes. Self-assessment and task-selection skills are important aspects of self-regulated learning in which students decide what is to be their own assignments and solve their problems [16].

Real-life supports the students' understanding of science. This fact gives a challenge for teachers to be creative for preparing teaching materials especially for science topic that has abstract representation. One kind of solution is a teacher can use endoscopic video that has commonly used by a health practitioner. There are three-dimensional high-definition and twodimensional high-definition video systems for representing a real process in the human body system [17]. Video may have a certain value for student preparation in science classes because it is more engaging [18] and video can clearly show an abstract or hard-to-visualize phenomenon [19].

Students' learning outcomes are influenced by many factors. Internal factors such as motives, skills and previous academic achievements play a positive and significant effect on students' learning outcomes [20] [21] [22]. Closeness and intensity of interaction with the instructors in the form of instructor delivering information, encouraging the learner, or providing feedback. In addition, this can include the learner interacting with the instructor by asking questions, or communicating with the instructor regarding course activities [23] [24]. The media can either be in the form of text, audio or videotape, CD-ROM, computer program, or online communication was found to be a significant predictor of student satisfaction and had a larger effect on the achievement of learning outcomes [25].

With respect to the discussions above, it can be stated that comic strips and endoscopic video may be used as a learning aid in the science classroom. The objectives of this study were to examine the learning outcomes and to explore the contributing factors that drive students to achieve the learning outcomes.

\section{Methods}

A quasi-experimental design was employed in this study. A Quasi-experiment consists of two classes, one as the experimental group and one as the control group but no set artificially. Because random settings can interrupt the student composition [26]. Moreover, the random selection of classrooms is quite impracticable. So that, quasi-experiment fitted to educational research [27]. The participants were university students in the science education major from batch 2015 and 2016. Batch 2015 consisted of 22 Students (3 Males and 19 Females) while batch 2016 consisted of 25 students ( 1 Male and 24 Females). The classes were assigned in this study based on their previous required course (Structure and Function of Organisms) in which 
both classes have no significant difference in their class score average. Batch 2015 was assigned as an endoscopic video class while batch 2016 was assigned as comic strips class.

The endoscopic video was a National Geographic documentary video taken from YouTube in the following link: https://www.youtube.com/watch?v=-JP4wAvZkMo\&t=193s (in minute 23:00 to 28:30) while comic strips were created and developed by a research team from Science Education Study Program, Faculty of Mathematics and Science Education, Universitas Pendidikan Indonesia. At the end of the treatment (in the human digestion process), both classes were required to fill an online quiz about in Edmodo Application and to choose one of three provided option (internal motivation, Lecturer/Instructor and Media: comic and endoscopic video) that contributes most on their learning outcomes of the topic. The Mann-Whitney U test was used to test for differences between learning outcomes of endoscopic video class and comic strips class. The test was used because the data do not meet the requirements of the parametric test. The data was categorized as a small sample.

\section{Results and Discussion}

\subsection{Student's Academic Achievement}

A Mann-Whitney U Test revealed no significant difference in learning achievement from both classes $(\mathrm{Md}=70, \mathrm{n}=22)$ and females $(\mathrm{Md}=80, \mathrm{n}=25), \mathrm{U}=246,5, \mathrm{z}=-0.86, \mathrm{p}=.38, \mathrm{r}=$ .12. This finding suggests that both endoscopic video and comic strip are able to accommodate students learning.

Comic plays a role to facilitate learning by providing humor and imagination. Humor in the comic in Figure 1 as one example how can comic stimulates the reader's positive emotional and intrinsic motivation to improve their interest in learning of science [2]. The storyline of the comic allows the students to use their imagination to increase reading motivation and interest [10] [11]. In addition, the visual associations provided by the comics support the understanding of abstract concepts [12]. In terms of student achievement, science comics engage middle-lever achievers more than high-level achievers [8], and comics in science education can engage and convey science knowledge among a broad diversity of students [13].

On the other hand, endoscopic video enables the students to observe the concrete process that occurs in the human digestive system which they can only imagine before starting from the process that undergoes in the mouth until the anus. Thus, the use of video can clearly show an abstract or hard-to-visualize phenomenon [19]. Figure 2 shows an image of the movement of the esophagus in the human digestive system used in the lesson. 


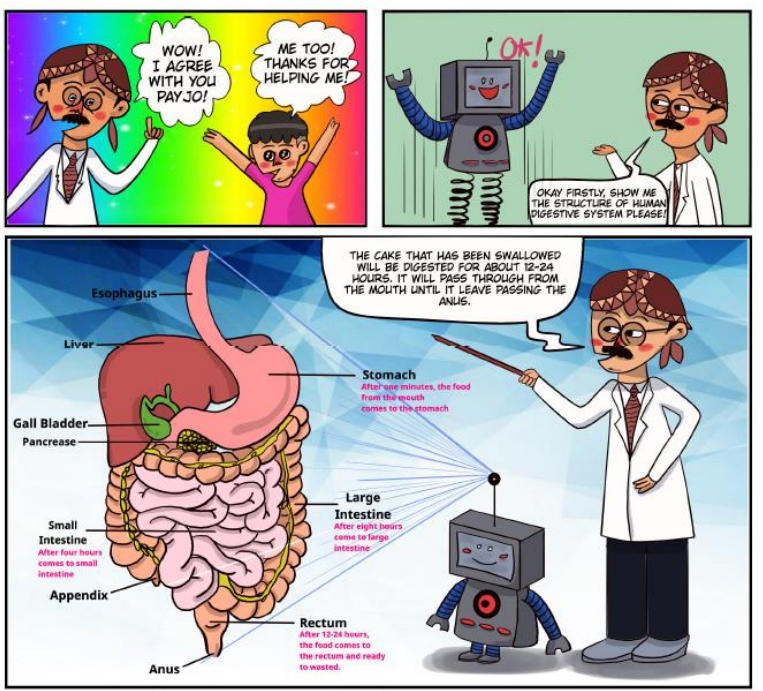

Fig. 1. Sample of digestion process explained by the character from the comic.

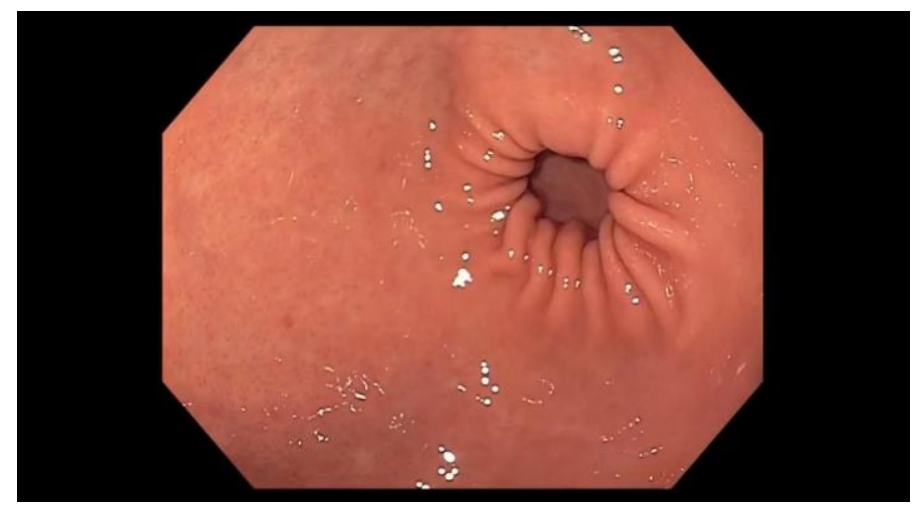

Fig. 2. Sample of esophagus movement in the digestion process of the video footage.

\subsection{Factors Contributing to student' Learning Outcomes.}

Figure 3 shows the contributing factors to students learning outcomes in learning the human digestion process. The data are drawn from the total student's responses from endoscopic video and comic strip class. Overall, internal motivation has the highest contribution to student's learning outcomes (38\%), followed by lecturer/instructor (34\%) and the least was the media (28\%). From this finding, it can be inferred that university students have a strong internal motivation to accomplish their course because they are an independent learner. Students' academic outcomes are influenced by many factors. Internal factors such as motives, skills and previous academic achievements play a positive and significant effect on students' academic achievement [20] [21] [22]. 


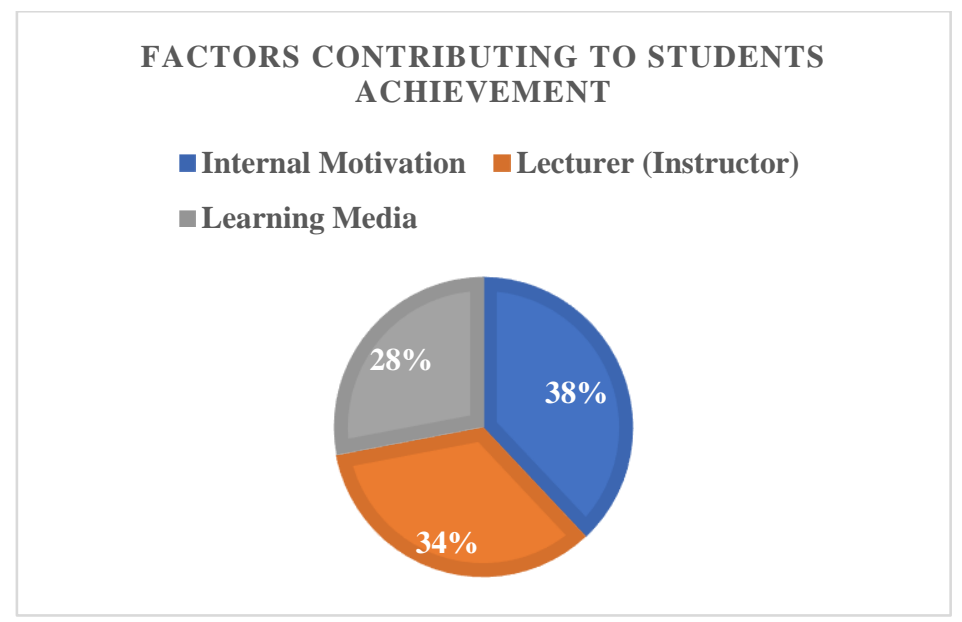

Fig. 3. Factors contributing to student's learning achievement.

Motivating students in the classroom e.g. being welcoming, responsive and explicit. Whilst not necessarily directly affecting students' skills in independent learning, the connections made between teachers and students in the classroom can motivate students to learn outside the classroom. Closeness and intensity of interaction with the instructors in the form of instructor delivering information, encouraging the learner, or providing feedback. In addition, this can include the learner interacting with the instructor by asking questions, or communicating with the instructor regarding course activities is important to support student's learning achievement [23] [24].

Although media is the least contributing factor, but the media for teaching must be well prepared because the media can either be in the form of text, audio or videotape, CD-ROM, computer program, or online communication was found to be a significant predictor of student satisfaction and had a larger effect on the achievement of learning outcomes [25].

\section{Conclusion}

We conclude that both media were able to facilitate students learning outcomes but motivating students' personal motives was also essential due to the nature of university students as an independent learner.

\section{References}

[1] Negrete, A.: Constructing A Comic To Communicate Scientific Information About Sustainable Development And Natural Resources In Mexico. Procedia-Social and Behavioral Sciences, Vol. 103, No. 2013, 200-209 (2013)

[2] Lin, S. F., Lin, H. S., Lee, L., \& Yore, L. D.: Are science comics a good medium for science communication? The case for public learning of nanotechnology. International Journal of Science Education, Part B, Vol. 5, No. 3, 276-294 (2015) 
[3] Hosler, J., \& Boomer, K. B.: Are comic books an effective way to engage nonmajors in learning and appreciating science?. CBE-Life Sciences Education, Vol 10, No. 3, 309-317 (2011)

[4] Tatalovic, M.: Science comics as tools for science education and communication: a brief, exploratory study. Journal of Science Communication, Vol. 8, No. 4, A02 (2009)

[5] Dallacqua, A. K., \& Peralta, L. R.: Reading and (re) writing Science Comics: A study of informational texts. The Reading Teacher, Vol. 73, No. 1, 111-118 (2019)

[6] Kim, D. H., Jang, H. G., Shin, D. S., Kim, S. J., Yoo, C. Y., \& Chung, M. S.: Science Comic Strips. Journal of Education and Learning, Vol. 1, No. 2, 65-71 (2012)

[7] Hosler J., Boomer K. B.: Are comic books an effective way to engage non-majors in learning and appreciating science? CBE Life Sci. Educ. Vol. 10, No. 3, 309-17 (2011)

[8] Lin, S. F., \& Lin, H. S.: Learning nanotechnology with texts and comics: the impacts on students of different achievement levels. International Journal of Science Education, Vol. 38, No. 8, 1373-1391 (2016)

[9] Tatalovic, M.: Science comics as tools for science education and communication: a brief, exploratory study. Journal of Science Communication, Vol. 8, No. 4, A02 (2009)

[10] Kerneža, M., \& Košir, K.: Comics as a literary-didactic method and their use for reducing gender differences in reading literacy at the primary level of education. Center for Educational Policy Studies Journal, Vol. 6, No. 2, 125-149 (2016)

[11] Di Raddo, P.: Teaching chemistry lab safety through comics. Journal of Chemical Education, Vol. 83, No. 4, 571 (2006)

[12] Trnová, E., Trna, J., \& Vacek, V.: The roles of cartoons and comics in science education. M. Costa, B. Dorio, M. Kireš. HSci2013. Educating for Science and through Science (240-244). Košice: PJ Šafarik University (2013)

[13] Spiegel, A. N., McQuillan, J., Halpin, P., Matuk, C., \& Diamond, J.: Engaging teenagers with science through comics. Research in science education, Vol. 43, No. 6, 2309-2326 (2013)

[14] Derry, S. J., Pea, R. D., Barron, B., Engle, R. A., Erickson, F., Goldman, R., ... \& Sherin, B. L.: Conducting video research in the learning sciences: Guidance on selection, analysis, technology, and ethics. The Journal of the Learning Sciences, Vol. 19, No. 1, 3-53 (2010)

[15] Zhang, D., Zhou, L., Briggs, R. O., \& Nunamaker Jr, J. F.: Instructional video in e-learning: Assessing the impact of interactive video on learning effectiveness. Information \& management, 43(1), 15-27 (2006)

[16] Raaijmakers, S. F., Baars, M., Schaap, L., Paas, F., Van Merriënboer, J., \& Van Gog, T.: Training self-regulated learning skills with video modeling examples: Do task-selection skills transfer? Instructional Science, 46(2), 273-290 (2018)

[17] Zang, X., Huang, H. L., Xie, B., Liu, J., \& Guo, H. M.: A comparative study of three-dimensional high-definition and two-dimensional high-definition video systems in totally endoscopic mitral valve replacement. Journal of thoracic disease, 11(3), 788 (2019)

[18] Stockwell, B. R., Stockwell, M. S., Cennamo, M., \& Jiang, E.: Blended learning improves science education. Cell, 162(5), 933-936 (2015)

[19] Dash, S., Kamath, U., Rao, G., Prakash, J., \& Mishra, S.: Audio-visual aid in teaching "fatty liver". Biochemistry and Molecular Biology Education, 44(3), 241-245 (2016)

[20] Aden, A. A., Yahye, Z. A., \& Dahir, A. M. The effect of student's attendance on academic performance: a case study at simad university mogadishu. Academic Research International, 4(6), 409 (2013)

[21] Desalegn, A. A., Berhan, A., \& Berhan, Y.: Absenteeism among medical and health science undergraduate students at Hawassa University, Ethiopia. BMC medical education, 14(1), 81 (2014)

[22] Credé, M., Roch, S. G., \& Kieszczynka, U. M.: Class attendance in college: A meta-analytic review of the relationship of class attendance with grades and student characteristics. Review of Educational Research, 80(2), 272-295 (2010)

[23] Sher, A.: Assessing the relationship of student-instructor and student-student interaction to student learning and satisfaction in web-based online learning environment. Journal of Interactive Online Learning, 8(2) (2009) 
[24] Chaudhuri, J. D.: Stimulating intrinsic motivation in millennial students: A new generation, a new approach. Anatomical sciences education (2019)

[25] Chan, S., \& Bose, D.: Engage Online Learners: Design Considerations for Promoting Student Interactions. In Handbook of Research on Strategic Management of Interaction, Presence, and Participation in Online Courses (pp. 328-349). IGI Global (2016)

[26] Creswell, J. W.: Educational research: Planning, conducting, and evaluating quantitative (pp. 146166). Upper Saddle River, NJ: Prentice Hall (2002)

[27] Cohen, L., Manion, L., \& Morrison, K.: Res

earch methods in education. Routledge (2002)

[28] Hsin, W. J., \& Cigas, J.: Short videos improve student learning in online education. Journal of Computing Sciences in Colleges, 28(5), 253-259 (2013) 